\title{
Theme-Based Book Review: Shifting Views of Public Sector Corruption
}

\author{
Christopher L. Atkinson ${ }^{1}$ iD
}

Accepted: 14 August 2021 / Published online: 3 September 2021

(c) The Author(s), under exclusive licence to Springer Science+Business Media, LLC, part of Springer Nature 2021

\begin{abstract}
This theme-based book review considers three recent titles related to public sector corruption: Populism and corruption: The other side of the coin, edited by Jonathan Mendilow and Eric Phelippeau; Critical perspectives on public systems management in India, by Amar KJR Nayak and Ram Kumar Kakani; and Handbook on corruption, ethics and integrity in public administration, edited by Adam Graycar.
\end{abstract}

Keywords Government · Corruption · Book reviews · Populism

\section{Introduction}

Corruption is a tremendous problem facing the public sector around the world. It results in waste of public resources, slowing of growth in the private sector, and further erosion of trust between citizens and government. It also leads to failure of government programs, and makes it less likely that efforts to encourage public participation in government will be fruitful (Moldogaziev \& Liu, 2021).

While corruption is clearly a problem, it is also a misunderstood concept, as reflected in continuing consideration of the topic in print. Works on public sector corruption are consistently on offer from scholarly and popular venues, and for good reason. The problem of public corruption remains of great interest to researchers, but also to citizens and those in government, elected and appointed. Low levels of trust in government have long been a concern, but something is arguably different about the present context and the predicament of government, and of public officials who seek to provide good value for the public dollar, and to meet the challenge of serving increasingly diverse and complex publics.

Christopher L. Atkinson

Catkinson1@uwf.edu

1 Department of Administration and Law, University of West Florida, 11000 University Parkway,

Bldg 70, Pensacola, FL 32514, USA 
The link between politics and administration is a blur for many citizens; any distinction, challenged by practice and portrayal, becomes less useful as discourse has become more tribal and less informed. Hard work in the public sector continues, most of the time, but the focus of media and politicians alike turns to negative portrayals of public administrators, programs, and a supposed environment of swindling to be reformed and reigned in. Long-term engagement and trust in the public sector is readily exchanged for short-run political gains, election wins, and creation and maintenance of cults of personality. While political will can be key to resolving public corruption, it is a complicated problem and political will alone cannot resolve it (Ankamah \& Khoda, 2018). Making matters more difficult is that corruption is often in the eye of the beholder, having more to do with the power of people calling out corruption than any universal standard of acceptability or appropriateness (Senior, 2004).

This theme-based book review considers three recent titles related to public sector corruption: Populism and corruption: The other side of the coin, edited by Jonathan Mendilow and Eric Phelippeau; Critical perspectives on public systems management in India, by Amar KJR Nayak and Ram Kumar Kakani; and Handbook on corruption, ethics and integrity in public administration, edited by Adam Graycar.

Jonathan Mendilow and Eric Phelippeau, editors (2021). Populism and corruption: The other side of the coin. Cheltenham, Glos, UK: Edward Elgar. 304 pp. ISBN 9781839109669 (Hbk, £100.00); 9781839109676 (E-book, £25.00).

Perhaps emblematic of our times, populism as a rejection of elites has been coopted by corrupt public officials, who seek to divert attention from their own corrupt practices. The conveyance of populist messages has been made efficient, if not weaponized, through availability of economical, truncated, easy to understand messages (Nguyen, 2017), in mass media and on social networks. Elsewhere, public resources are used by those aiming to enrich themselves privately under the guise of public benefit. Private sector interests have in many instances not simply reduced notions of public interest - they have replaced them entirely, where the private interest of a charismatic leader, and the interests of a diverse public, are supposedly one and the same. Populism has made it easier for many to dismiss what they see before them, and believe myth, like "faith in a glorious past" (Valarini \& Trombini, 2021, p. 146) instead, up to refashioning villains as heroes (Shafir, 2021). A large segment of the population might believe that a rich elite person can be just like them, and speak what is in their mind. In an upside-down world, government, not to be trusted and prone to lies, should be instead be entrusted to people prone to lying that have no idea how to run the public sector effectively, or worse, are a bunch of grifters and kleptocrats. The behaviors are illicit, to be sure, but a public that goes along with the scheme, regardless of political affiliation, is complicit.

In democracies, we have perhaps become accustomed to institutions providing stability in challenging times, through rational-legal means; populist candidates clearly drive the public's imagination - offering a return to simpler times, when outlooks were supposedly better, and opportunity abounded, for the low cost of dismantling an unfair, unjust elite system - and this poses a significant danger to stability and administrative competence. Instead of stability, populists offer the chance to engage in politically incorrect 'truth-telling', xenophobia, classism, and 
scapegoating, a soundbite at a time, to the point where nonsense like flouting norms and engaging in 'low culture'-speak starts to look like the root of revolution. The problem with this is that the more the public engages in fake participation - as a backdrop for some political reality TV program - the less likely it is that real participation, yielding development of programs that help move society forward, will occur or even be allowed to exist. Acemoglu, Egorov, and Sonin suggested that populism is "the implementation of policies receiving support from a significant fraction of the population, but ultimately hurting the economic interests of this majority" (2013, p. 772). Populism is not just a phenomenon of which to take note; it is potentially dangerous to its supporters and their interests.

Populism and Corruption: The Other Side of the Coin helps to uncover the link between the two sides of this figurative coin; its chapters coalesce into a whole that is at once thought-provoking and disturbing. After an introduction by Mendilow, three sections allow the reader to focus in on the attendant phenomena: how populism corrupts pluralist government, and the countering of supposedly corrupt elites with the notion of a pure people; a second section with national perspectives on the topic; and a concluding section that explores populism's costs, and analyzes its claims. The public corruption is less the stuff of entropy and decay of institutions, and more the destruction of structure and boundary to advance individual or group interests. Roman Chytilek, in a chapter on Central European populism (2021), makes the point that 'opposing corruption' can basically mean whatever the speaker wants it to mean, if it means anything at all. Rooting out corruption sounds like hard work, but it may not amount to anything of practical importance; while the public agrees that corruption is bad, agreement on a list of corrupt practices is fleeting, with some practices that are corrupt by definition being given a pass. Corrupt politicians call out their adversaries as corrupt (Shafir, 2021). The cycle is a wicked ouroboros, and corruption becomes less clear the longer the cycle exists. It is much more difficult to fix a broken system than to engage in light rhetorical flourish, and since corrupt officials have no interest in fixing the system, it continues unabated.

Thematically, the book emphasizes the importance of an educated public sector, able to withstand the winds of expectation and changing public priorities. It becomes clear through the book's chapters that interference with public programs exists in a variety of circumstances, with a profoundly negative cumulative effect on attainment of popular public ideals. Even though we are living in the world of this book, the authors are able to pull back enough to provide perspective, giving a fact-based, balanced view. The lessons of the book, notably about the use of anti-intellectualism in populism, are worth our attention, especially in light of society's apparent inability to respond well to disasters like COVID-19. While it is heartening to read work that calls out silliness like a 'pure people' engaging in a righteous battle against a corrupt elite or a fundamentally unjust government, it hurts to know that an effect of populism is a portion of the public that delights in creating and maintaining enemies and being gleefully wrong, even if their choices hurt themselves and others. Populism means that voters can believe that they have finally been heard, and were right all along, even when that is not true.

Corruption is a moving target, and so some chapters, especially those on the US and Israel, are not current with more recent developments. Even in those instances, 
many enlightening points are made that are worthwhile. Many times I was outraged by inappropriate comments of supposed leaders; these comments still carry the sting of willful misunderstanding and inexplicable hatred, and seem even more awful out of their original context. The rhetoric probably delighted supporters, even if it is madness, and that makes processing it more difficult.

Jonathan Mendilow and Eric Phelippeau have collected an excellent series of chapters on the connection of populism to corruption. The book makes a case that populism has moved beyond simple appeals and language to providing cover for active corruption - this is a message that needs to be heard, demonstrated and proven, and then believed. That said, I doubt that the book will be read by those that need to read it the most, so the most I can do is recommend it to readers of this journal. It is a worthwhile read.

Amar KJR Nayak and Ram Kumar Kakani (2021). Critical perspectives on public systems management in India: Through the Lens of District Administration. Abingdon, Oxon, UK: Routledge. 196 pp. ISBN 9780367540234 (Hbk, \$160 USD); 9781003084099 (E-book, \$48.95 USD).

Critical Perspectives on Public Systems Management in India focuses on the position of District Collector (or Magistrate) in the Indian Administrative Service. The authors have served as professors at Lal Bahadur Shastri National Academy of Administration, and so are privileged to teach administrative service officers. Where many books talk about citizen-centric government in a conceptual way, this book offers an inside look, giving rich, detailed examples of both rural and urban instances of high-quality governance, with constitutional values acting as a centering influence on the work of these young officers. The book uses the district collector position as a focus, but the result of the book is a picture of courage in the face of an exceedingly complex and often difficult public sector context, with lessons that are more broadly applicable globally.

The first chapter outlines district administration's role in Indian government, and how it has evolved. Readers are treated to an up-close view of the district collector job on a typical day. District collectors, like many public administrators, are often called to be jacks-of-all-trades. They are confronted with a wide range of activities, long workdays, and many commitments from all sides.

The next chapter considers public administration through various perspectives; effectiveness, efficiency, and sustainability figure heavily. The authors make a point to note how public administration does itself no favors in focusing on theory as applied to the business world, given the very different role of public officials. I think the use of national values is interesting, even if ideals can be difficult to achieve in practice. 'National' values are perhaps more what nations would have us know about them, than the ideals actually employed on a day-to-day basis, especially with political polarization existing in many nations.

Chapters on the two cases, Bhopal and Osmanabad, follow. It is easy to like these chapters, as the reader may feel like they have been on a journey to visit the places, and see the world from the perspective of the district collector assigned. They are a bit travelogue and history, but with much excellent detail on processes unique to the district, and interestingly, functional case studies within the district on pressing topics: farmer's concerns, development projects, childhood programs, and even the 
impact of climate change on local programs and prospects. District collectors have to process a lot of information and deal with influence, some of it undue, in the discharge of their duties. We see many instances of these district collectors working diligently to understand stakeholder needs, and to address them responsively.

A chapter critically analyzing the cases and public responsiveness is included, and the work is seen as both transactional and transformational. The authors suggest that the two cases are a microcosm of public administration: we see public servants under pressure, balancing interactions with the public, data and analysis, and program evaluation to achieve a ground-level implementation of an evolving vision of public service excellence. A chapter on the future of the district collector role completes the book. Here, recommendations are offered that can help public officials work more effectively, including in places known for corruption. Nayak and Kakani suggested that "bottom-up small-cluster based approaches of development administration could lead to holistic development of people and communities... when development plans are based on priorities and participation of people, their ownership of these projects increases" (2021, p. 160). Comments like this ring true, even though approaches to development, favoring elite interests, are common and deviate significantly from this ideal.

While the limitation of the book to two cases is notable, the approach nevertheless provides great detail on the district collector's role, the challenges that exist in the public operating environment, and opportunity for learning from this role and its context. I enjoyed the book, especially learning about these places in India and the near-heroic role of district collectors, and am pleased to recommend it. The book is short enough to potentially be of interest to a wider range of public administration readers, and the two cases might be useful in a classroom setting where a focus on real-life challenges and successes is needed for exemplar purposes. Scholars engaged in study of this area, this role or similarly situated roles, and the practice of stakeholder-involved governance, may find this book useful as well.

Adam Graycar, editor (2020). Corruption, ethics and integrity in public administration. Cheltenham, Glos, UK: Edward Elgar. 512 pp. ISBN 781789900903 (Hbk, \$295 USD); 9781789900910 (E-book, \$65 USD).

Handbook on corruption, ethics and integrity in public administration, part of Edward Elgar's extensive collection of handbooks for public management and administration, includes a variety of thought-provoking short works on public sector corruption and related topics. After an introductory chapter by editor Graycar (2020a, b), 31 chapters follow arranged in four main sections: a group of chapters on vulnerabilities of public administration to corruption; a sectoral approach to corruption, including chapters on corruption in healthcare and education, and local government-level corruption; ten chapters of national case studies of corruption; and finally, responses in public administration to corruption, providing typologies for understanding and recommendations on a path forward for not only combating corruption, but fostering public integrity.

A number of chapters provide exceptional considerations of certain topics, in a particularly engaging manner. Macaulay's (2020) chapter on public administration morality and virtue, and Howlett's (2020) chapter on corruption and malfeasance, are clear and vital. Pyman's (2020) chapter on sectoral approaches to addressing 
corruption raises the importance of context to understanding and addressing corruption; its point about sensemaking resonated with me as a former government practitioner. I read the chapter on corruption in education with great interest, and found Heyneman's (2020) account both involving and harrowing. For practitioners called to create or modify programs to deal with public corruption, the handbook offers several chapters (Villaneuve et al., 2020; Huberts \& van Montfort, 2020, for example) that illustrate program frameworks with useful typologies. Jon Quah's (2020) chapter on the strength of anti-corruption efforts in Singapore offers great clarity of purpose, with lessons readily applicable to other places.

The book does suffer in places for what might be a recitation of old viewpoints that are increasingly outmoded given the changing context of the public sector. The Mendilow and Phelippeau book brings this rapidly changing context into high relief, and some of the chapters in the Graycar book, such as the piece on trends and drivers of public administration, could seem out of date/out of touch with current stresses. The book makes an effort to bring in discussion of organized crime and its influence on public sector corruption, but perhaps due to the nature of the collection as a handbook, and its short chapters providing an overview but lacking in detail, this comes across as unfinished and deserving of more attention. The section on national-level case studies is interesting, but there did not appear to be any specific order to presentation of the chapters. More attention would have been welcome on the topic of whistleblowers - one chapter examined this topic, but peer-level checks for public integrity are important (a point this book makes), and may be the last, or only, line of defense for eliminating instances, notably grievous instances, of public corruption. It could be argued that the important role of whistleblowers is ill understood by the public, and not valued in that it can impact political fortunes. A lack of protection for administrators encourages partisanship and allows for growth and development of authoritarian tendencies in government, when neutral competence and simple adherence to rules and process are not valued.

The collection is wide-ranging, allowing for excellent coverage of topics of interest to both scholars and practitioners. While it is perhaps inescapable that a collection of this scope and breadth will have some unevenness, the quality of the chapters is generally high, with thoughtful contributions from an international scholar and practitioner team. Each chapter builds to form a coherent whole of knowledge on the subject, but the chapters can be taken individually to provide quick and useful understanding on specific issues that may be encountered in either research or practice. As such, the book is recommended for library collections, but would also be of great interest to public sector leaders, seeking to understand corruption as a phenomenon, but with interest in developing useful structures to help achieve public integrity and provide accountability, in the interest of improving trust between citizens and government. 


\section{Synthesis}

While there is considerable value in the books presented in this review, the sum total of the discussion, even with Nayak and Kakani's inspiring and positive consideration of excellence in public administration in India (2021), is that the public sector is on the defensive, and efforts to address extant corruption and encourage positive organizational culture often fail, for a wide range of reasons. The contributors to the Populism and Corruption collection together paint a discouraging picture of today's difficult context. Political realities are perhaps more apt to tear societies apart than bring them together, and public administration - itself composed of appointed, unelected workers - cannot mend the breach, because the breach is purposeful, and the cleavages in society useful for particular needs. A book like Graycar's edited volume may not inspire a positive view of what is possible in public administration, even if the collection does end on an encouraging note. The way forward is less clear: the issue of public trust of government institutions is worrying, and resolving corruption might well require "restoring trust in the integrity of politics" (Rohac et al., 2017, p. 382) - a difficult challenge, if not an impossibility with certain segments of the population.

Successes still occur, even amid all the challenges we face in the public service. Even when environments are prone to corruption, it does not necessarily follow that public administrators are corrupt. Even when negative examples are more likely to receive coverage, there are still people who hold ideals, especially constitutionled ideals, closely. These are the officials that do well for the public, when no one is watching. For the expertise and stability that they bring, and because they meet that challenge to a broad public obligation, if they are not owed a debt of gratitude, they are at least owed the ability to do their jobs without influence from self-dealing officials or segments of the public that, with an arrogant braggadocio, engage in untruths and demand their opinions result in wholesale institutional dismantling, or else, the system must fall.

People may sometimes be self-serving, mad, or delusional, and be made this way by public forces with questionable motives. Weak governments cave to the loudest voices, even if they make less sense. Populism aside, if governments collapse in favor of self-dealing individuals and indefensible beliefs, we will have lost capacities that we need now and in the future. Corruption undercuts system abilities to address public needs and to maintain vital public programs. It is precisely because most public servants are reasonable members of the reality-based community that society has not collapsed utterly. These books demonstrate the challenge of corruption, but also the hope that exists in excellent public service by the best among us. Readers can decide for themselves if the current setting is different than previous times, enough to sound a general alarm in defense of public institutions and administrators.

Declarations The author has no relevant financial or non-financial interests to disclose.

The author certifies that he has no affiliations with or involvement in any organization or entity with any financial interest or non-financial interest in the subject matter or materials discussed in this manuscript. The author has no financial or proprietary interests in any material discussed in this article. 
Conflict of Interest The author has no conflicts of interest to declare that are relevant to the content of this article.

Informed Consent This research does not involve human participants and/or animals.

Because the work does not involve human subjects, informed consent is not applicable.

\section{References}

Acemoglu, D., Egorov, G., \& Sonin, K. (2013). A political theory of populism. Quarterly Journal of Economics, 128(2), 771-805.

Ankamah, S. S., \& Khoda, M. E. (2018). Political will and government anti-corruption efforts: What does the evidence say? Public Administration \& Development, 38(1), 3-14.

Chytilek, R. (2021). Corrupt elites, pure people and double standards? Attitudes of Central European populist and mainstream political party sympathizers to systemic and individual corruption. In J. Mendilow \& E. Phelippeau (Eds.), Populism and corruption: The other side of the coin (pp. 57-87). Edward Elgar.

Graycar, A. (2020a). Corruption and public administration. In A. Graycar (Ed.), Handbook on corruption, ethics and integrity in public administration (pp. 1-9). Edward Elgar.

Graycar, A. (Ed.). (2020b). Handbook on corruption, ethics and integrity in public administration. Edward Elgar.

Heyneman, S. P. (2020). Corruption in the education sector. In A. Graycar (Ed.), Handbook on corruption, ethics and integrity in public administration (pp. 129-138). Edward Elgar.

Howlett, M. (2020). Dealing with the dark side of policy-making: Corruption, malfeasance and the volatility of policy mixes. In A. Graycar (Ed.), Handbook on corruption, ethics and integrity in public administration (pp. 67-79). Edward Elgar.

Huberts, L., \& van Montfort, A. (2020). Building ethical organizations: The importance of organizational integrity systems. In A. Graycar (Ed.), Handbook on corruption, ethics and integrity in public administration (pp. 449-462). Edward Elgar.

Macaulay, M. (2020). Virtue and morality in public administration: Values-driven leadership in publicsector agencies. In A. Graycar (Ed.), Handbook on corruption, ethics and integrity in public administration (pp. 43-55). Edward Elgar.

Moldogaziev, T. T., \& Liu, C. (2021). Public sector corruption and perceived government performance in transition. Governance, 34(2), 475-504.

Nguyen, K. H. (2017). Rhetoric in neoliberalism. In K. H. Nguyen (Ed.), Rhetoric in Neoliberalism (pp. 1-14). Palgrave Macmillan.

Pyman, M. (2020). Redefining sectors: A more focused approach to tackling corruption. In A. Graycar (Ed.), Handbook on corruption, ethics and integrity in public administration (pp. 98-114). Edward Elgar.

Quah, J. S. T. (2020). Singapore's effective anti-corruption recipe: Lessons for other countries. In A. Graycar (Ed.), Handbook on corruption, ethics and integrity in public administration (pp. 360-376). Edward Elgar.

Rohac, D., Kumar, S., \& Johansson Heino, A. (2017). The wisdom of demagogues: Institutions, corruption and support for authoritarian populists. Economic Affairs, 37(3), 382-396.

Senior, I. (2004). Corruption, the government and the private sector: Why it matters and what can be done. Economic Affairs, 24(2), 22-29.

Shafir, M. (2021). Corruption and populism in East-Central post-communist Europe: The egg, the hen and the omelet. In J. Mendilow \& E. Phelippeau (Eds.), Populism and corruption: The other side of the coin (pp. 153-189). Edward Elgar.

Valarini, E., \& Trombini, M. E. (2021). Populist grammar, politicians and judges: A case study of political corruption in Brazil. In J. Mendilow \& E. Phelippeau (Eds.), Populism and corruption: The other side of the coin (pp. 129-152). Edward Elgar.

Villaneuve, J., Magellini, G., \& Heide, M. (2020). Typologies of anti-corruption frameworks. In A. Graycar (Ed.), Handbook on corruption, ethics and integrity in public administration (pp. 29-42). Edward Elgar.

Publisher's Note Springer Nature remains neutral with regard to jurisdictional claims in published maps and institutional affiliations. 